\title{
Comparative Analysis of the Determinant Factors of Return on Assets between Islamic Commercial Banks (BUS) and Islamic Business Units (UUS)
}

\author{
Lucky Nugroho $^{1^{*}}$, Akhmad Amien Mastur $^{2}$, Ulfa $^{3}$, Tri Wahyono ${ }^{4}$, Soeharjoto \\ 1,3,4 Universitas Mercu Buana, Jakarta, Indonesia \\ ${ }^{12}$ Student Doctoral Program on Islamic Economics and Finance, Universitas Trisakti, Indonesia \\ ${ }^{5}$ Universitas Trisakti, Jakarta, Indonesia \\ 1lucky.nugroho@mercubuana.ac.id,2amien_mastur@yahoo.co.id,3ulfairsal@gmail.com, \\ ${ }^{4}$ tri_wahyono@mercubuana.ac.id, ${ }^{5}$ soeharjoto@trisakti.ac.id \\ * Corresponding author
}

\begin{abstract}
This study aimed to analyze and compare the factors that affect the return on assets (ROA) of Islamic commercial banks (BUS) and Islamic business units (UUS). This study's independent variables are NPF, FDR, and MSMEs. The study used the quantitative method, with multiple regression approaches in analyzing the research data. The results of this study show that the BUS NPF has a negative and significant impact on the BUS ROA; the BUS FDR has a positive and insignificant impact on the BUS ROA; the BUS MSMEs portion of the BUS loan distribution has a negative and insignificant impact on the BUS ROA; the UUS NPF has a negative and significant impact on the UUS ROA; the UUS FDR has a positive and significant impact on the UUS ROA; and the MSMEs' portion of the UUS loan distribution has a positive and significant impact on the UUS ROA.
\end{abstract}

Keywords: BUS, UUS, Return on Asset, Non-Performing Financie, Financing to Deposit Ratio, MSME financing

\section{Analisis Perbandingan Determinan Faktor Return on Asset antara Bank Umum Syariah (BUS) dengan Unit Usaha Syariah (UUS)}

\begin{abstract}
Abstrak
Penelitian ini bertujuan untuk menganalisa perbandingan variabel-variabel yang mempengaruhi return on asset pada Bank Umum Syariah (BUS) dengan Unit Usaha Syariah (UUS). Adapun variable-variabel bebas yang digunakan pada penelitian ini adalah non performing financing, financing to deposit ratio dan porsi penyaluran pinjaman usaha mikro, kecil dan menengah (UMKM). Metode yang digunakan adalah kuantitatif dengan pendekatan regresi berganda dalam melakukan analisa penelitian ini. Hasil dari penelitian ini diketahui bahwa NPF BUS berdampak negatif dan signifikan terhadap ROA BUS; FDR BUS berdampak postif dan tidak signifikan terhadap ROA BUS; porsi penyaluran pinjaman UMKM BUS berdampak negatif dan tidak signifikan terhadap ROA BUS; NPF UUS berdampak negatif dan signifikan terhadap ROA UUS; FDR UUS berdampak positif dan signifikan terhadap ROA UUS; Porsi penyaluran pinjaman UMKM UUS berdampak positif dan signifikan terhadap ROA UUS.
\end{abstract}

Kata kunci: BUS, UUS, ROA, NPF, FDR, Pembiayaan UMKM

\section{INTRODUCTION}

The number of Islamic banks in Indonesia has increased since the enforcement of Law No. 21 of 2008 concerning Islamic banking (Prasetiyo, 2012). Furthermore, such law helped provide a more explicit operational basis for and supports the development of Islamic banks. Based on the Islamic Country Index survey results from the Global Islamic Finance Report, 
Indonesia's Islamic finance industry in 2018 has had achievements, having been ranked first in the Islamic finance industry (KNKS, 2019). The Islamic Country Index assessment includes (i) the number of Islamic financial institutions; (ii) regulations related to Islamic finance; (iii) Islamic financial assets; (iv) educational and cultural support for Islamic finance; and (iv) the completeness of the infrastructure supporting the Islamic financial industry. The growth of the number of Islamic financial institutions in Indonesia consisting of Islamic commercial banks (BUS) and Islamic business units (UUS) is shown below.

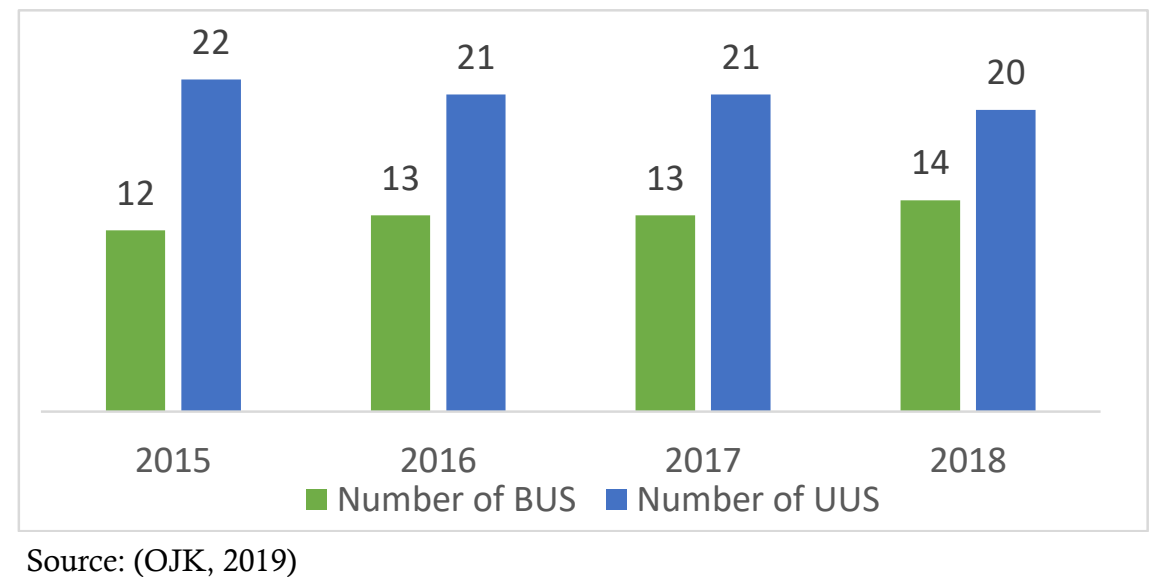

Figure 1. Growth of the numbers of Islamic commercial banks (BUS) and Islamic business units (UUS) from 2015 to 2018

However, the overall number of Islamic banks (BUS and UUS) in Indonesia did not grow from 2015 to 2018; there were only 34 (Figure 1). Furthermore, the previous research conducted by Nugroho et al. (2017) showed that the development of Islamic banks in Indonesia requires intervention from the government so it would not be based only on the number of banks in existence but also on such banks' Islamic products and financial services that can be accessed by all the Muslim communities.

Furthermore, based on Figure 1 above, the number of BUS in Indonesia in 2015 (12) increased to 14 in 2018. Meanwhile, the number of UUS decreased from 22 in 2015 to 20 in 2018. This phenomenon, however, does not mirror the growth of the numbers of BUS and UUS outlets in the country within the same time frame. The number of BUS outlets decreased from 1,990 in 2015 to 1,875 in 2019; there were thus 115 outlets that closed. Meanwhile, the number of UUS outlets increased from 311 in 2015 to 354 in 2018; there were thus 43 new outlets. However, in the research conducted by Nugroho et al. (2020), the number of Islamic bank outlets has not significantly affected the poverty alleviation due to the Islamic banks' centralized outlet locations in the cities in the provinces and districts. Furthermore, the consideration in the opening of Islamic bank outlets is still increasing the revenue of Islamic banks by opening outlets in strategic locations where potential customers can be acquired (Widigdo et al., 2016). Figure 2 shows the development of the numbers of BUS and UUS outlets from 2015 to 2018. 


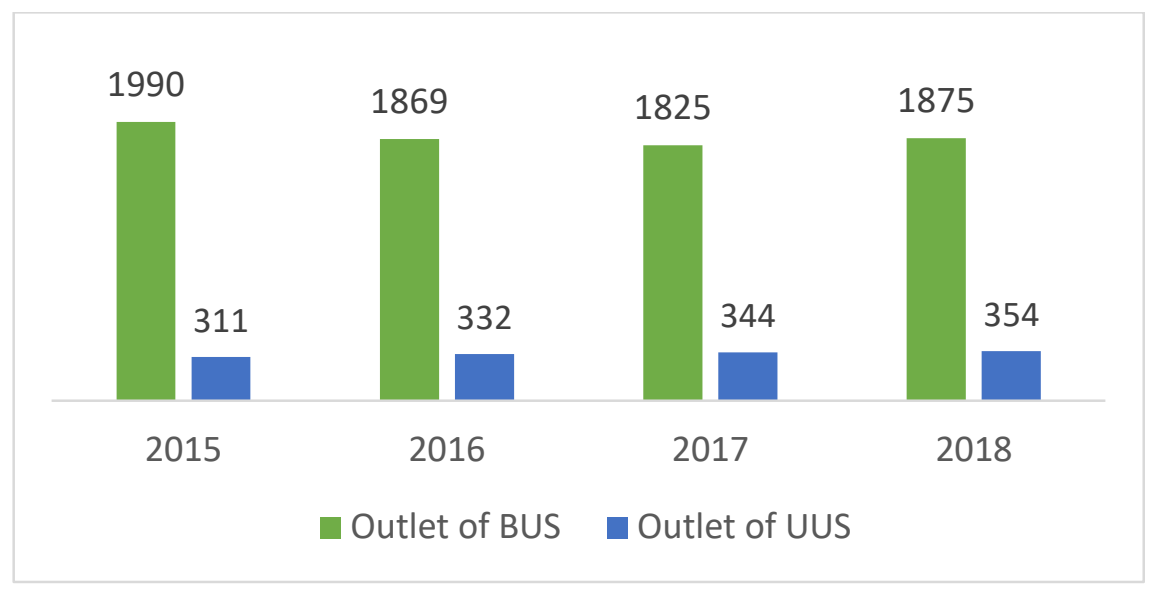

Source: (OJK, 2019)

Figure 2. Growth of the numbers of Islamic commercial bank (BUS) and Islamic business unit (UUS) outlets from 2015 to 2018

The going concern is a vital aspect in the operations of companies, including Islamic banks (DeFond et al., 2002). Islamic banks will close their outlets that continue to experience losses. Thus, profitability is essential for Islamic banks (Hidayah, Badawi, \& Nugroho, 2019). According to Abd Razak (2019) and Cebeci (2012), however, the consideration of Islamic banks' operational sustainability should be based not only on profit but also on such banks' continued existence so they can continue to provide benefits for the all communities. Thus, as long as Islamic bank outlets can cover their operational costs, their closure can be postponed. Further, the financial indicator of an Islamic bank's capacity to generate income from its business activities is the return on assets (ROA) (Demirgüç-Kunt \& Huizinga, 2010). That is, if an Islamic bank manages its assets well, its income may increase, which will improve its ROA. Figure 3 shows the BUS and UUS ROA from 2012 to 2018.

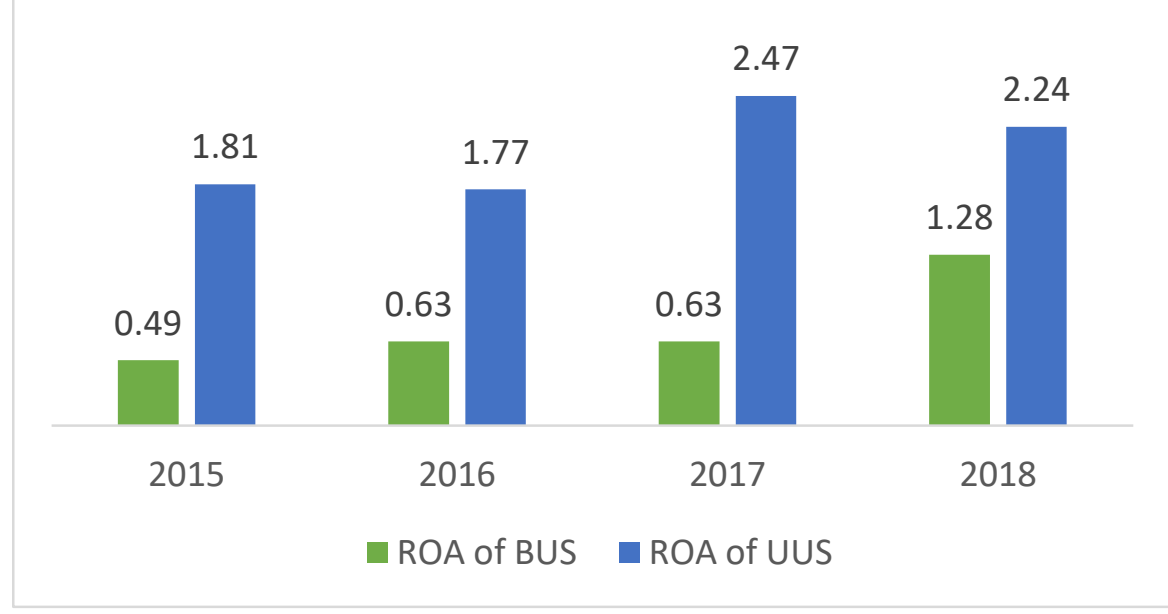

Source: (OJK, 2019)

Figure 3. Return on assets of the Islamic commercial banks (BUS) and Islamic business units (UUS) from 2015 to 2018

As shown in the figure above, the BUS ROA was lower than the UUS ROA in the years 2015-2018. Furthermore, the BUS ROA increased from $0.49 \%$ in 2015 to $1.28 \%$ in 2018 , a significant $161 \%$ increase. Meanwhile, the UUS ROA increased from $1.81 \%$ in 2015 to $2.24 \%$ 
in 2018 , only a $24 \%$ increase. Figure 1 shows that the outlets that were closed within the said period were those that were not productive. Thus, even though there was a decrease in the number of BUS and UUS outlets within the said period, the BUS and UUS ROA significantly increased.

However, the ROA will not increase if the Islamic banks' assets are dominated by nonperforming assets, which will decrease such banks' income and liquidity. In the conventional banks, bad assets are called non-performing loans (NPLs) while in Islamic banks, they are called non-performing finance (NPF). The BUS and UUS NPF in 2015-2018 experienced significant improvements, but the BUS and UUS closed outlets that were not productive and that had bad assets and were thus unable to maintain their performance. The number of BUS with NPF has decreased by $33 \%$, from $4.84 \%$ in 2015 to $3.26 \%$ in 2018 . As for the number of UUS with NPF, it decreased by $20 \%$, from $3.03 \%$ in 2015 to $2.41 \%$ in 2018 . Figure 4 shows the BUS and UUS NPF data for 2015-2018.

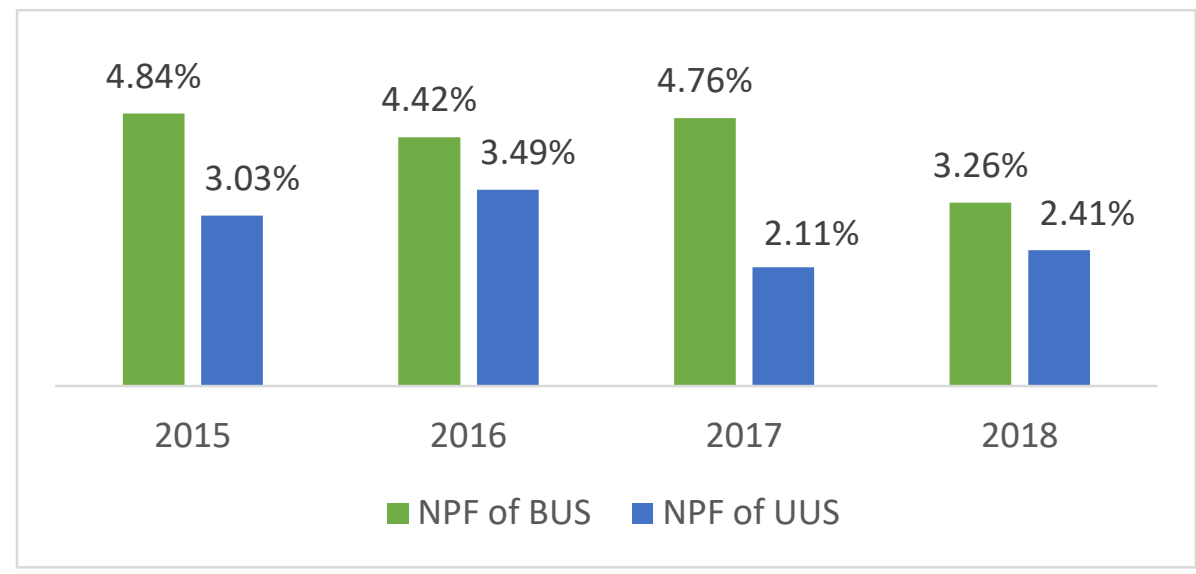

Source: (OJK, 2019)

Figure 4. Islamic commercial banks' (BUS) and Islamic business units' (UUS) nonperforming finance from 2015 to 2018

According to Agur (2012) and Amidu and Wolfe (2013), a bank's main activity is managing the funds it gets from the public, with its main products being savings and loans. Sharia banks operate based on the Sharia principles; the products and services must be based on Sharia contracts. The implementation of the Sharia contract aims to provide justice to all Sharia bank customers. An Islamic bank is a bank that aims to provide benefits for all the communities and should carry out its intermediary function properly. The indicator of Islamic banks' intermediation is the financing-to-deposit ratio (FDR), which signifies the banks' channeling of their funds to the public through loans (Chotib \& Utami, 2016; Fathonih et al., 2019; Nastiti \& Kasri, 2019). The better an Islamic bank's intermediation function, the higher the bank's ROA. The BUS and UUS FDR decreased in 2015-2018. This trend can be seen in Figure 5. 
As can be seen in Figure 5, the BUS FDR decreased from $88.03 \%$ in 2015 to $78.53 \%$ in 2018 , an $11 \%$ decrease. Meanwhile, the UUS FDR decreased albeit only by $2 \%$, from $104.88 \%$ in 2015 to $103.22 \%$ in 2018 .

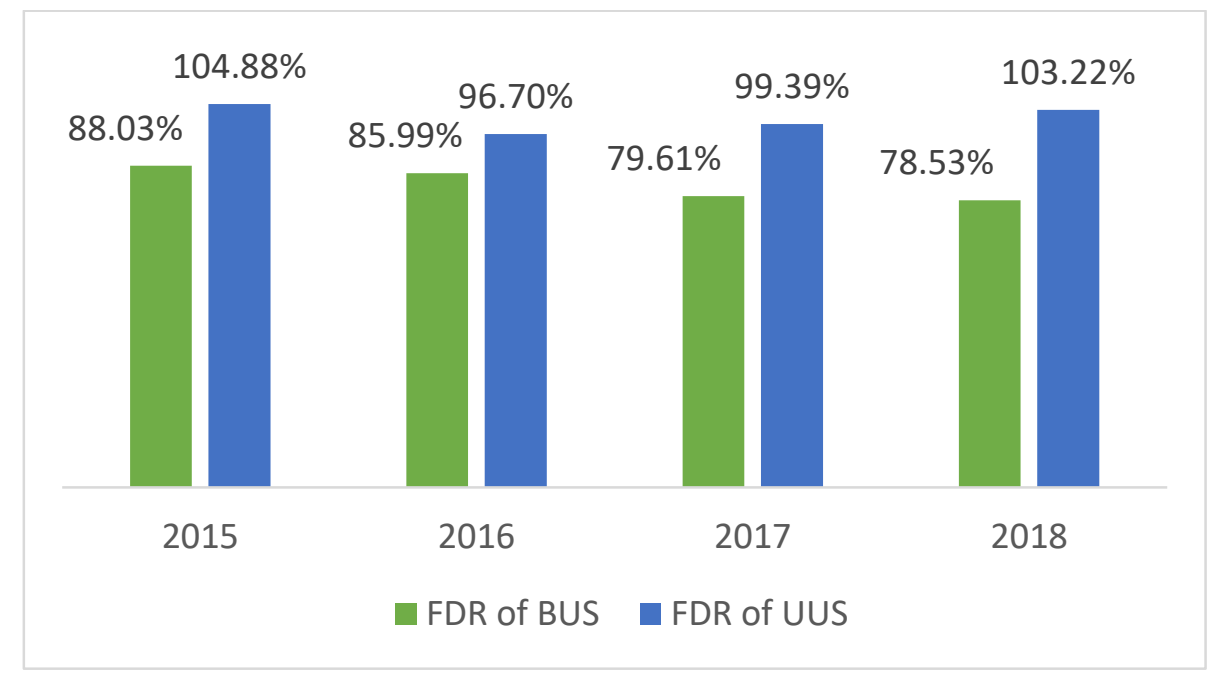

Source: (OJK, 2019)

Figure 5. Financing-to-deposit ratio of the Islamic commercial banks (BUS) and Islamic business units (UUS) from 2015 to 2018

Islamic banks are banks concerned with alleviating poverty through their products and services (Dusuki, 2008). Thus, better lending to MSMEs will improve Islamic banks' reputation, which will increase the BUS or UUS revenue. Based on the foregoing phenomena, this study aimed to answer the research questions below.

1. Does non-performing finance affect the return on assets of Islamic commercial banks (BUS)?

2. Does the financing-to-deposit ratio affect the return on assets of Islamic commercial banks (BUS)?

3. Does the micro, small, and medium enterprise segment financing affect the return on assets of Islamic commercial banks (BUS)?

4. Does non-performing finance affect the return on assets of Islamic business units (UUS)?

5. Does the financing-to-deposit ratio affect the return on assets of Islamic business units (UUS)?

6. Does the micro, small, and medium enterprise segment financing affect the return on assets of Islamic business units (UUS)?

7. Are there differences between the effects of non-performing finance, financing-to-deposit ratio, and micro, small, and medium enterprise segment financing on the return on assets of Islamic commercial banks (BUS) and of Islamic business units (UUS)?

Furthermore, as can be gleaned from the aforementioned research questions, the purpose of this study was to analyze the factors that affect the BUS and UUS ROA in terms of NPF, FDR, and loan disbursements to the MSME segment. The benefit of this research is that it can provide information regarding how to manage BUS and UUS so as to maintain their operational sustainability and financial stability. This study's results can also add to the literature related to the BUS and UUS, especially in terms of profitability, as the study aimed 
to analyze the BUS's and UUS's profitability on the basis of their lending activities to the MSME segment.

\section{METHOD}

\section{Estimation Model}

This research employed a quantitative approach using multiple regression analysis. Such model was used to attain this study's objective by comparing the determinant profitability factors of BUS and UUS. The method employed in this research is shown in Figure 6.

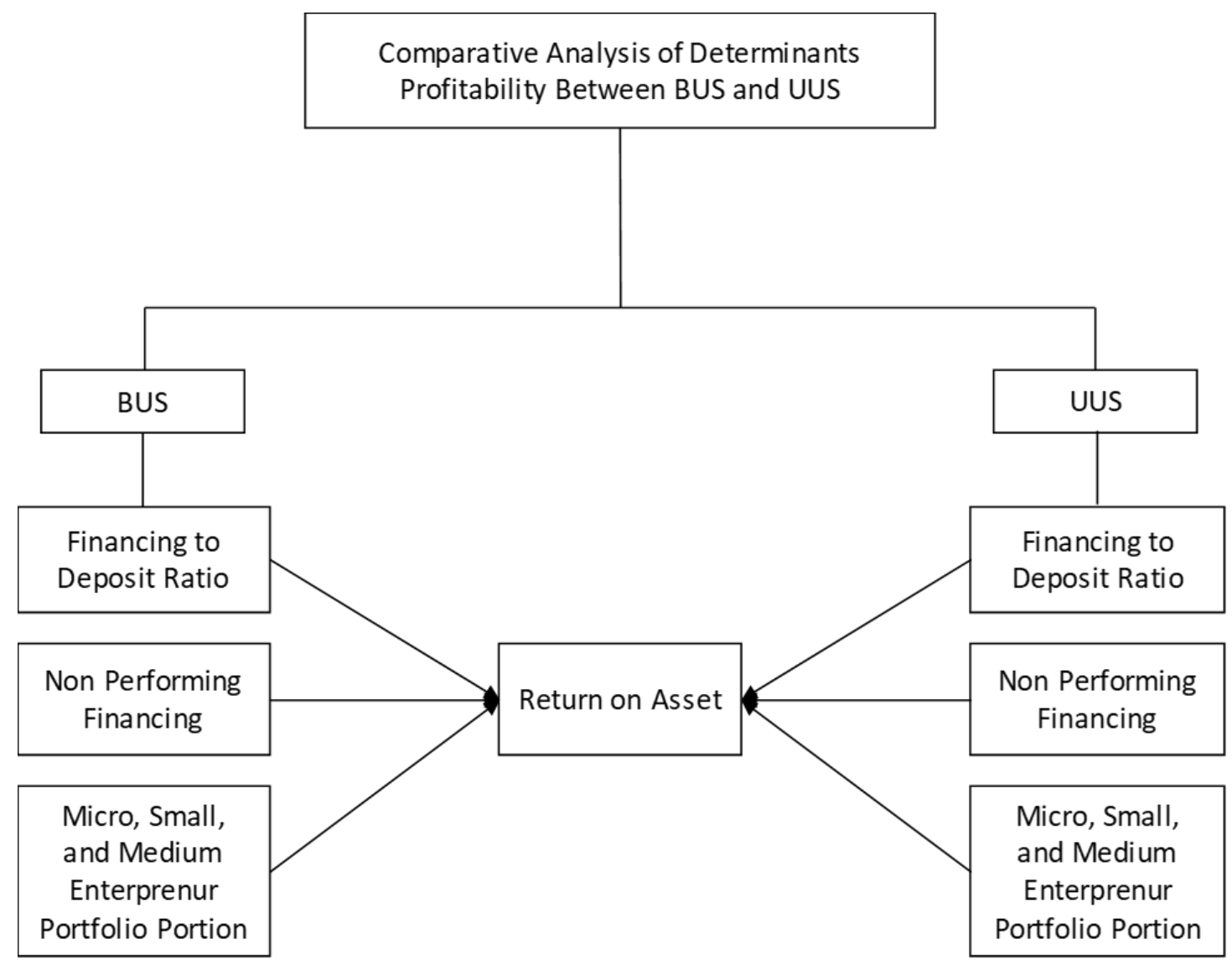

Figure 6. Research conceptual framework

Moreover, as indicated in Figure 6, the independent variables that were used in this study were non-performing finance (NPF), financing-to-deposit ratio (FDR), and micro, small, and medium enterprises' (MSMEs) portfolio portion, and the dependent variable was return on assets (ROA). Therefore, the equation that was used in this study is as follows:

where:

$$
\begin{aligned}
& \text { BUS (ROA)t }=\beta_{0}+\beta_{1}(\text { FDR }) t+\beta_{2}(\text { NPF }) t+\beta_{3}(\text { MSMEs }) t+\varepsilon t \ldots \\
& \text { UUS (ROA) } t=\beta_{0}+\beta_{1}(\text { FDR })_{t}+\beta_{2}(\text { NPF }) t+\beta_{3}(\text { MSMEs }) t+\varepsilon t \ldots
\end{aligned}
$$

\footnotetext{
BUS = Islamic commercial banks

UUS = Islamic business units

ROA $=$ Return on assets

FDR = Financing-to-deposit ratio
} 


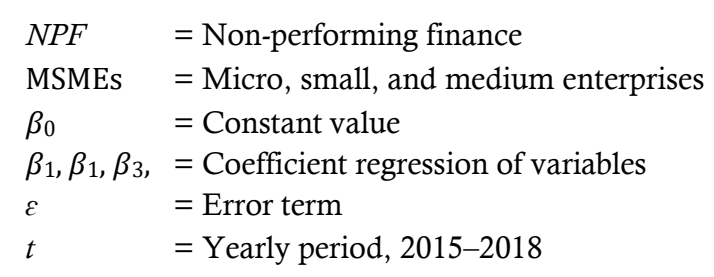

The study population consisted of the BUS and UUS registered with the Financial Services Authority in Indonesia in 2015-2018. During this period, there was a phenomenon of decreasing numbers of BUS and UUS outlets. Table 1 and 2 list the BUS and UUS outlets that existed in 2015-2018, respectively.

Table 1. Research population (BUS outlets in 2015-2018)

\begin{tabular}{cl}
\hline No. & BUS outlet name \\
\hline 1 & PT Bank Aceh Syariah \\
2 & PT BPD Nusa Tenggara Barat Syariah \\
3 & PT Bank Muamalat Indonesia \\
4 & PT Bank Victoria Syariah \\
5 & PT Bank BRISyariah \\
6 & PT Bank Jabar Banten Syariah \\
7 & PT Bank BNI Syariah \\
8 & PT Bank Syariah Mandiri \\
9 & PT Bank Mega Syariah \\
10 & PT Bank Panin Dubai Syariah \\
11 & PT Bank Syariah Bukopin \\
12 & PT BCA Syariah \\
13 & PT Bank Tabungan Pensiunan Nasional Syariah \\
14 & PT Maybank Syariah Indonesia \\
\hline
\end{tabular}

Table 2. Research population (UUS outlets in 2015-2018)

\begin{tabular}{cl}
\hline No. & UUS outlet name \\
\hline 1 & PT Bank Danamon Indonesia, Tbk \\
2 & PT Bank Permata, Tbk \\
3 & PT Bank Maybank Indonesia, Tbk \\
4 & PT Bank CIMB Niaga, Tbk \\
5 & PT Bank OCBC NISP, Tbk \\
6 & PT Bank Sinarmas \\
7 & PT Bank Tabungan Negara (Persero), Tbk \\
8 & PT BPD DKI \\
9 & PT BPD Daerah Istimewa Yogyakarta \\
10 & PT BPD Jawa Tengah \\
11 & PT BPD Jawa Timur, Tbk \\
12 & PT BPD Sumatera Utara \\
13 & PT BPD Jambi \\
14 & PT BPD Sumatera Barat
\end{tabular}




\begin{tabular}{cl}
\hline No. & UUS outlet name \\
\hline 16 & PT BPD Sumatera Selatan dan Bangka Belitung \\
17 & PT BPD Kalimantan Selatan \\
18 & PT BPD Kalimantan Barat \\
19 & PD BPD Kalimantan Timur \\
20 & PT BPD Sulawesi Selatan dan Sulawesi Barat \\
\hline
\end{tabular}

Purposive sampling was used for the sample selection in this study. This method is used when the sample members are explicitly selected on the basis of the research objectives; that is, on the basis of the key characteristics of the members of the population from which the sample will be selected. Those who do not possess the specified characteristics will not be selected as samples. Below are the study's inclusion criteria.

1. BUS and UUS units in Indonesia with complete annual financial reports for 2015-2018 provided to the researchers that (1) have been published in the Financial Services Authority in Indonesia or on the websites of the respective BUS and UUS units and (2) with the financial year ending on December 31 (to avoid the effect of partial timing in calculating the proxies of the independent and dependent variables)

2. BUS and UUS units in Indonesia with the data required for measuring the variables used for the research for the period 2015-2018

Table 3. Sample selection based on the study's inclusion criteria (BUS)

\begin{tabular}{lr}
\multicolumn{1}{c}{ Criteria } & Amount \\
\hline Number of BUS units & 14 \\
Negative return on assets (BUS) & 4 \\
Outlier data & 1 \\
Sample of data & 9 \\
Years of observation & 4 \\
\hline Total data for observation & 36 \\
\hline
\end{tabular}

Table 4. Sample selection based on the study's inclusion criteria (UUS)

\begin{tabular}{lr}
\multicolumn{1}{c}{ Criteria } & Amount \\
\hline Number of UUS units & 20 \\
Negative return on assets (UUS) & 6 \\
Sample of data & 14 \\
Years of observation & 4 \\
\hline Total data for observation & 56 \\
\hline
\end{tabular}

\section{Operationalization Variable}

The data for several data categories that were used for the regression model analysis were sourced from OJK (Otoritas Jasa Keuangan-Financial Services Authority). For the analysis, the years from 2015 to 2018 were used. The operationalization data for each dependent and independent variable and the hypotheses regarding the relationship between these variables are explained in Table 5. 
Jurnal Economia, 17(1), April 2021, 124-140

Table 5. Operationalization of variables

\begin{tabular}{cccc}
\hline Variable & Operationalization & Unit & Hypothesis \\
\hline ROA & Net income & & \\
\cline { 2 - 3 } NPF & $\begin{array}{c}\text { Total assets } \\
\text { Bad financing }\end{array}$ & & Negative \\
\cline { 2 - 3 } FDR & $\begin{array}{c}\text { Total financing } \\
\text { Total financing }\end{array}$ & $\%$ & Positive \\
\cline { 2 - 3 } MSMEs & $\begin{array}{c}\text { Total funding } \\
\text { MSME financing }\end{array}$ & $\%$ & Positive \\
\cline { 2 - 3 } & Total financing & $\%$ & \\
\hline
\end{tabular}

\section{RESULTS AND DISCUSSION}

The SPSS Statistics version 25 statistical software was used for statistical processing based on the regression method and the operationalization of the independent and dependent variables, as shown in Table 5. The regression results are shown in Table 6 and 7.

Table 6. Multiple linear regression test (BUS) results

\begin{tabular}{|c|c|c|c|c|c|c|}
\hline \multicolumn{7}{|c|}{ Coefficients } \\
\hline & \multirow{2}{*}{ Model } & \multicolumn{2}{|c|}{$\begin{array}{l}\text { Unstandardized } \\
\text { coefficients }\end{array}$} & \multirow{2}{*}{$\begin{array}{c}\text { Standardized } \\
\text { coefficients } \\
\text { Beta }\end{array}$} & \multirow[t]{2}{*}{$\mathrm{t}$} & \multirow[t]{2}{*}{ Sig. } \\
\hline & & $\mathrm{B}$ & Std. error & & & \\
\hline & (Constant) & 0.831 & 1.491 & & 0.558 & 0.581 \\
\hline & X1(NPF) & -0.361 & 0.126 & -0.514 & -2.875 & 0.007 \\
\hline & X2(FDR) & 0.018 & 0.017 & 0.141 & 1.026 & 0.313 \\
\hline & X3(MSMEs) & -0.014 & 0.013 & -0.182 & -1.019 & 0.316 \\
\hline
\end{tabular}

* Dependent variable: $\mathrm{Y}(\mathrm{ROA})$

Table 7. Multiple linear regression test (UUS) results

\begin{tabular}{|c|c|c|c|c|c|c|}
\hline & & & Coefficients $^{*}$ & & & \\
\hline & Model & Unstandardized & coefficients & $\begin{array}{l}\text { Standardized } \\
\text { coefficients }\end{array}$ & $\mathrm{t}$ & Sig. \\
\hline & & $\mathrm{B}$ & Std. error & Beta & & \\
\hline & (Constant) & -0.347 & 0.883 & & -0.393 & 0.696 \\
\hline & X1(NPF) & -0.334 & 0.124 & -0.296 & -2.693 & 0.010 \\
\hline 1 & X2(FDR) & 0.022 & 0.006 & 0.409 & 3.777 & 0.000 \\
\hline & X3(MSMEs) & 0.079 & 0.024 & 0.361 & 3.276 & 0.002 \\
\hline
\end{tabular}

* Dependent variable: $\mathrm{Y}(\mathrm{ROA})$

Furthermore, as shown in Table 6 and 7, aside from SPSS Statistics version 25, regression equations (3) and (4) were also used for the statistical processing.

$$
\begin{aligned}
& \text { BUS }(\mathrm{ROA})=0.831-0.361(\mathrm{NPF})+0.018(\mathrm{FDR})-0.014(\mathrm{MSME})+\varepsilon_{\mathrm{t}} \\
& \text { UUS }(\mathrm{ROA})=-0.347-0.334(\mathrm{NPF})+0.022(\mathrm{FDR})+0.079(\mathrm{MSME})+\varepsilon \mathrm{t}
\end{aligned}
$$

Using multiple regression, the data processing met the classical test assumptions, including the normality test, multicollinearity test, autocorrelation test, and 
heteroscedasticity test. Table 8 and 9 show the normality test results of the BUS and UUS.

As can be seen in Table 8, the Kolmogorov-Smirnov $Z$ value was 0.099 and the asymp. sig. (2-tailed) value was 0.200 , which is more than 0.05 . Thus, it can be said that the data from the BUS variables were normally distributed.

Table 8. Results of the normality test using the one-sample Kolmogorov-Smirnov test (BUS)

\begin{tabular}{llr}
\hline & & Unstandardized residual \\
\hline N & & 36 \\
Normal parameters ${ }^{\mathrm{a}, \mathrm{b}}$ & Mean & 0.0000000 \\
Most extreme differences & Std. deviation & 0.78729502 \\
& Absolute & 0.099 \\
& Positive & 0.099 \\
& Negative & -0.070 \\
Test statistic & & 0.099 \\
Asymp. sig. (2-tailed) & & $0.200^{\text {c, }}$ \\
\hline
\end{tabular}

a. Normal test distribution

b. Calculated from the data

c. Lilliefors significance correction

d. Lower bound of the real significance

Table 9. Results of the normality test using the one-sample Kolmogorov-Smirnov test (UUS)

\begin{tabular}{llr}
\hline & & Unstandardized residual \\
\hline Normal parameters ${ }^{\mathrm{a}, \mathrm{b}}$ & & 56 \\
& Mean & 0.0000000 \\
Most extreme differences & Std. deviation & 1.39274018 \\
& Absolute & 0.071 \\
& Positive & 0.071 \\
Test statistic & Negative & -0.053 \\
Asymp. sig. (2-tailed) & & 0.071 \\
\hline
\end{tabular}

a. Normal test distribution

b. Calculated from the data

c. Lilliefors significance correction

d. Lower bound of the true significance

As can be seen in Table 9, the Kolmogorov-Smirnov $Z$ value was 0.071 and the asymp. sig. (2-tailed) value was 0.200 , which is more than 0.05 . Thus, it can thus be said that the data from the BUS variables were normally distributed.

Furthermore, the multicollinearity test was used to analyze the tolerance value and the variance inflation factor (VIF) value. Table 10 shows the test results for each variable.

As can be seen in Table 10, the tolerance value calculation results show that there were no independent variables that had a tolerance value of less than 0.10 , which means that there were no correlations among the independent variables. The results of the calculation of the VIF value show the same: none of the independent variables had an VIF value of more than 10. Thus, it can be concluded that there was no multicollinearity among the independent variables in the multiple regression model (BUS). 
Table 10. Multicollinearity test results (BUS)

\begin{tabular}{|c|c|c|c|c|c|c|c|c|}
\hline & \multicolumn{8}{|c|}{ Coefficients $^{*}$} \\
\hline & \multirow[t]{2}{*}{ Model } & \multicolumn{2}{|c|}{$\begin{array}{l}\text { Unstandardized } \\
\text { coefficients }\end{array}$} & \multirow{2}{*}{$\begin{array}{c}\text { Standardized } \\
\text { coefficients } \\
\text { Beta }\end{array}$} & \multirow[t]{2}{*}{$\mathrm{t}$} & \multirow[t]{2}{*}{ Sig. } & \multicolumn{2}{|c|}{$\begin{array}{c}\text { Collinearity } \\
\text { statistics }\end{array}$} \\
\hline & & B & Std. error & & & & Tolerance & VIF \\
\hline & (Constant) & 0.831 & 1.491 & & 0.558 & 0.581 & & \\
\hline & X1(NPF) & -0.361 & 0.126 & -0.514 & -2.875 & 0.007 & 0.533 & 1.876 \\
\hline 1 & X2(FDR) & 0.018 & 0.017 & 0.141 & 1.026 & 0.313 & 0.910 & 1.099 \\
\hline & X3(MSMEs) & -0.014 & 0.013 & -0.182 & -1.019 & 0.316 & 0.538 & 1.860 \\
\hline
\end{tabular}

* Dependent variable: $\mathrm{Y}(\mathrm{ROA})$

Table 11. Multicollinearity test results (UUS)

\begin{tabular}{|c|c|c|c|c|c|c|c|c|}
\hline & \multicolumn{8}{|c|}{ Coefficients $^{*}$} \\
\hline & \multirow[t]{2}{*}{ Model } & \multicolumn{2}{|c|}{$\begin{array}{l}\text { Unstandardized } \\
\text { coefficients }\end{array}$} & \multirow{2}{*}{$\begin{array}{l}\text { Standardized } \\
\text { coefficients } \\
\text { Beta }\end{array}$} & & \multirow[t]{2}{*}{ Sig. } & \multicolumn{2}{|c|}{$\begin{array}{c}\text { Collinearity } \\
\text { statistics }\end{array}$} \\
\hline & & B & Std. error & & & & Tolerance & VIF \\
\hline & (Constant) & -0.347 & 0.883 & & -0.393 & 0.696 & & \\
\hline & X1(NPF) & -0.334 & 0.124 & -0.296 & -2.693 & 0.010 & 0.917 & 1.090 \\
\hline 1 & X2(FDR) & 0.022 & 0.006 & 0.409 & 3.777 & 0.000 & 0.947 & 1.056 \\
\hline & X3(MSMEs) & 0.079 & 0.024 & 0.361 & 3.276 & 0.002 & 0.912 & 1.097 \\
\hline
\end{tabular}

* Dependent variable: $\mathrm{Y}(\mathrm{ROA})$

As can be seen in Table 11, the tolerance value calculation results show that there were no independent variables that had a tolerance value of less than 0.10 , which means that there were no correlations among the independent variables. The results of the calculation of the VIF value show the same: none of the independent variables had an VIF value of more than 10. Thus, it can be concluded that there was no multicollinearity among the independent variables in the multiple regression model (UUS).

Furthermore, a heteroscedasticity test was performed using the Glejser statistical test.

Table 12 shows the results of the heteroscedasticity test.

Table 12. Results of the heteroscedasticity test using the Glejser test (BUS)

\begin{tabular}{|c|c|c|c|c|c|c|}
\hline \multicolumn{7}{|c|}{ Coefficients $^{*}$} \\
\hline & \multirow[t]{2}{*}{ Model } & \multicolumn{2}{|c|}{ Unstandardized coefficients } & \multirow{2}{*}{$\begin{array}{c}\text { Standardized } \\
\text { coefficients }\end{array}$} & \multirow[t]{2}{*}{$\mathrm{t}$} & \multirow[t]{2}{*}{ Sig. } \\
\hline & & $\mathrm{B}$ & Std. error & & & \\
\hline \multirow{4}{*}{1} & (Constant) & -3.662 & 4.942 & & -0.741 & 0.464 \\
\hline & X1NPF & 0.137 & 0.092 & 0.286 & 1.488 & 0.147 \\
\hline & $\mathrm{X} 2 \mathrm{FDR}$ & 0.864 & 1.097 & 0.125 & 0.787 & 0.437 \\
\hline & X3MSMEs & 0.195 & 0.196 & 0.190 & 0.994 & 0.328 \\
\hline
\end{tabular}

* Dependent variable: Abs_RES2 
Table 12 shows that all the variables had a significant probability value above 0.05 . It can thus be concluded that the regression model was free of heteroscedasticity symptoms (BUS).

Table 13. Results of the heteroscedasticity test using the Glejser test (UUS)

\begin{tabular}{|c|c|c|c|c|c|c|}
\hline \multicolumn{7}{|c|}{ Coefficients $^{*}$} \\
\hline & \multirow{2}{*}{ Model } & \multicolumn{2}{|c|}{ Unstandardized coefficients } & $\begin{array}{l}\text { Standardized } \\
\text { coefficients }\end{array}$ & \multirow{2}{*}{$\mathrm{t}$} & \multirow{2}{*}{ Sig. } \\
\hline & & B & Std. error & Beta & & \\
\hline \multirow{4}{*}{1} & (Constant) & 0.226 & 0.513 & & 0.440 & 0.662 \\
\hline & $\mathrm{X} 1(\mathrm{NPF})$ & 0.002 & 0.072 & 0.004 & 0.028 & 0.978 \\
\hline & $\mathrm{X} 2(\mathrm{FDR})$ & 0.007 & 0.003 & 0.276 & 2.018 & 0.049 \\
\hline & X3(MSMEs) & 0.008 & 0.014 & 0.077 & 0.549 & 0.585 \\
\hline
\end{tabular}

* Dependent variable: ABS_RES

Table 13 shows that all the variables had a significant probability value above or equal to 0.05 . It can thus be concluded that the regression model was free from heteroscedasticity symptoms (UUS). Also, to be able to compare and analyze the data, the descriptive statistics of the variables in this study are provided in Table 14.

Table 14. Descriptive statistical test results (BUS)

\begin{tabular}{|c|c|c|c|c|c|}
\hline Model & $\mathrm{N}$ & Minimum & Maximum & Mean & Std. deviation \\
\hline $\mathrm{X} 1(\mathrm{NPF})$ & 36 & 0.04 & 4.97 & 2.0264 & 1.51622 \\
\hline X2(FDR) & 36 & 69.44 & 100.87 & 85.5619 & 8.42071 \\
\hline X3(MSMEs) & 36 & 2.78 & 35.85 & 15.9846 & 8.35050 \\
\hline $\mathrm{Y}(\mathrm{ROA})$ & 36 & 0.02 & 4.27 & 1.2708 & 1.06510 \\
\hline
\end{tabular}

Moreover, as can be seen in Table 14, the maximum BUS NPF was still below the requirement (5\%), and the average BUS NPF was at an adequate level (2.03\%). Nevertheless, there were BUS units that channeled loans above $100 \%$ for the FDR variable while the average FDR was maintained at the $85.56 \%$ level. The average loan disbursement ratio to MSMEs was $15.98 \%$.

Table 15. Descriptive statistical test results (UUS)

\begin{tabular}{|c|c|c|c|c|c|}
\hline Model & $\mathrm{N}$ & Minimum & Maximum & Mean & Std. deviation \\
\hline $\mathrm{X} 1(\mathrm{NPF})$ & 56 & 0.00 & 7.45 & 1.2943 & 1.62493 \\
\hline $\mathrm{X} 2(\mathrm{FDR})$ & 56 & 55.42 & 239.85 & 108.8261 & 33.88161 \\
\hline X3(MSMEs) & 56 & 2.31 & 56.26 & 25.5047 & 14.13096 \\
\hline $\mathrm{Y}(\mathrm{ROA})$ & 56 & 0.05 & 7.61 & 2.8957 & 1.83305 \\
\hline
\end{tabular}


Nevertheless, as can be seen in Table 15, the maximum NPF of UUS exceeded the $5 \%$ requirement $(7.45 \%)$. However, the average NPF of UUS was at a controlled level $(1.029 \%)$. As for the FDR variable, the UUS units distributed loans above $200 \%$ while their average FDR was $108.82 \%$, which indicates that they were very aggressive in spreading loans to the communities. The variable of loan disbursement ratio to MSMEs averaged $25.50 \%$.

\section{DISCUSSION}

Comparison of the NPF effects on the BUS and UUS ROA

The data processing results obtained using the multiple regression method (Table 6 and 7) show that the NPF has a negative and significant effect on the BUS and UUS ROA. This study's results are in line with those of the previous research conducted by Almunawwaroh and Marliana (2018), where it was found that an increase in NPF will significantly reduce the ROA. Thus, both BUS and UUS must maintain the quality of their loans to their customers. However, Riyadi and Yulianto (2014) and Wibowo and Syaichu (2013) found that when the amount of NPF is still low, it will not have a significant effect on the decreased of ROA.

Moreover, to maintain the quality of their financing, according to Nugroho et al. (2018), Islamic banks must be able to anticipate the ability of their account officers to analyze the feasibility of financing. This will allow lending to the public to provide optimal income for the Islamic banking industry. However, Islamic banks must also improve their Islamic financial literacy, especially in relation to the concept of debt, particularly the principles that must be understood by customers in debt, which include:

1. non-indebtedness except in emergencies (Alam et al., 2020; Prasetiyo, 2012);

2. intention to pay off one's debt (Yunus \& Muslimin, 2020);

3. borrowing as needed (Alam et al., 2020; Prasetiyo, 2012);

4. obligation to pay debts on time (Yunus \& Muslimin, 2020);

5. obligation to fulfill one's promises and being honest and kind to one's lender (Beekun \& Badawi, 2005);

6. informing one's lender as soon as possible if one will not yet be able to pay his debt (Rammal \& Zurbruegg, 2007);

7. finding a way to pay one's debt if one encounters problems in doing so (Rammal \& Zurbruegg, 2007);

8. thanking one's lender and praying for him for his kindness (Afkar, 2017).

Internal efforts related to improving the competence of the account officers for both BUS and UUS and external efforts to increase customer debt literacy have implications on reducing lending risk. The BUS and UUS NPF can be well maintained with an average BUS NPF of $2.02 \%$ and an average UUS NPF of $1.3 \%$.

Comparison of FDR effects on the BUS and UUS ROA

The FDR has a positive but insignificant effect on the BUS ROA. Meanwhile, for UUS, the FDR has a positive and significant effect on the increase in ROA. This is due to the more aggressive lending by UUS compared to BUS. The aggressiveness of UUS in terms of loan distribution is indicated by the average UUS FDR of $108.82 \%$ compared to the average BUS 
FDR of $85.56 \%$. Nevertheless, the high level of loan disbursement made by UUS must be balanced with efforts to increase the number of savers so that the liquidity risk can be adequately mitigated. Central Bank (Bank Indonesia-BI) No. 17/11/PBI/2015 states that the maximum allowable FDR is $92 \%$. Thus, the UUS loan disbursement has exceeded the maximum stipulated ratio. However, UUS have a low NPF ratio, and loan distribution can provide them with an optimal income. A previous study also stated that in Islamic banks, the FDR has a positive and significant effect on the ROA because the high distribution of financing will benefit such banks (Erlangga et al., 2017). Meanwhile, Widyaningrum and Septiarini (2015) found that the distribution of financing has a positive but insignificant effect on the ROA because the FDRs of Islamic banks are still low or not optimal.

\section{Comparison of MSME effects on the BUS and UUS ROA}

The goals and principles of Islamic banks are different from those of the conventional banks. Islamic banks aim to provide benefits to the community and uphold the teachings of Islam in their totality. The principle of Islamic banking is to help the Muslim ummahs carry out their religion in kaffah or totality. Therefore, the operational principle of Islamic banks is to prohibit transactions containing elements of speculation, uncertainty, and injustice (Badawi \& Hidayah, 2018). Thus, according to Bukhari et al. (2020) and Hassan and Syafri Harahap (2010), an Islamic bank is a bank that has social concerns, focusing on poverty alleviation by providing loans to MSMEs. Table 6 and 7 indicate that the ratio of loan disbursement to MSMEs of BUS has a negative and insignificant effect on the BUS ROA. On the other hand, the ratio of UUS financing to MSMEs has a positive and significant effect on the UUS ROA. This is because the average loan disbursement to MSMEs of UUS is more significant than that of BUS. The portion of UUS financing to MSMEs reached $25.5 \%$ while the portion of BUS financing to MSMEs was only $15.9 \%$. This is on account of the low NPF and high FDR of UUS so that an increase in their loan disbursement to MSMEs increases their ROA significantly and optimally. Besides, a previous study also stated that the BUS do not focus on MSMEs because they consider these high-risk customers. Therefore, the BUS's MSME portfolio is lower than the UUS's MSME financing ratio (Nugroho \& Nugraha, 2020).

\section{CONCLUSION}

The Islamic banking industry in Indonesia is divided into two categories: Islamic commercial banks (BUS) and Islamic business units (UUS). These two categories of Sharia financial actors have different characteristics, so it is necessary to analyze their ability to generate profits. Based on the research results, the findings shown below were obtained.

1. The BUS NPF has a negative and significant impact on the BUS ROA.

2. The BUS FDR has a positive but insignificant impact on the BUS ROA.

3. The MSME portion of the BUS loan disbursement has a negative and insignificant impact on the BUS ROA.

4. The UUS NPF has a negative and significant impact on the UUS ROA.

5. The UUS FDR has a positive and significant impact on the UUS ROA. 
6. The MSME portion of the UUS loan disbursement has a positive and significant impact on the UUS ROA.

7. There are differences in the variables' effects on the ROA: for UUS, the NPF, FDR, and loan disbursement to MSMEs have significant effects. In contrast, for BUS, only the NPF has a significant effect on the ROA.

The aforementioned results signify that in channeling financing, both BUS and UUS must maintain their quality because the higher the NPF, the lower the profit, which impacts the ROA. Also, it was found in this study that for BUS, the distribution of financing represented by the FDR has a positive but insignificant effect on the ROA. In contrast, for UUS, the FDR has a positive and significant effect on the ROA. This can be because the focus of the BUS financing segment is different from that of the UUS financing segment: UUS focus on financing MSMEs while BUS do not. It can be seen that financing in the UUS MSME segment has a positive and significant impact on the UUS ROA.

On the other hand, BUS financing in the MSME segment has a negative and insignificant effect on the BUS ROA. The study results show that the focus of the BUS financing disbursement is not on the MSME segment or that the BUS NPF on the MSME segment financing distribution in the BUS is higher than the UUS NPF on the same. Therefore, on the basis of the results of this study, for further research on Islamic banks' profitability, it is suggested that the effect of the NPF in the MSME financing segment on the ROA be investigated for both the BUS and UUS.

\section{REFERENCES}

Abd Razak, A. H. (2019). Multiple Sharia' board directorship: a Maslahah (public interest) perspective. Journal of Islamic Marketing, 11(3), 745-764. https://doi.org/10.1108/JIMA10-2018-0185.

Afkar, T. (2017). Influence Analysis Of Mudharabah Financing And Qardh Financing To The Profitability Of Islamic Banking In Indonesia. AJIE - Asian Journal of Innovation and Entrepreneurship, $\quad$ 02(03), 340-351. $\quad$ Retrieved from https://journal.uii.ac.id/ajie/article/view/8355/7503.

Agur, I. (2012). Credit rationing when banks are funding constrained. North American Journal of Economics and Finance, 23(2), 220-227. https://doi.org/10.1016/j.najef.2012.01.002.

Alam, A., Dewi Permata Sari, \& Boby Habibi. (2020). Penyuluhan Etika Hutang Piutang Dalam Islam Di Dusun Bendosari Kabupaten Sukoharjo. Amaliah: Jurnal Pengabdian Kepada Masyarakat, 4(1), 1-13. https://doi.org/10.32696/ajpkm.v4i1.324.

Almunawwaroh, M., \& Marliana, R. (2018). Pengaruh Car, Npf Dan Fdr Terhadap Profitabilitas Bank Syariah Di Indonesia. Amwaluna: Jurnal Ekonomi Dan Keuangan Syariah, 2(1), 1-17. https://doi.org/10.29313/amwaluna.v2i1.3156.

Amidu, M., \& Wolfe, S. (2013). The impact of market power and funding strategy on bankinterest margins. European Journal of Finance, 19(9), 888-908. https://doi.org/10.1080/1351847X.2011.636833.

Badawi, A., \& Hidayah, N. (2018). The effect of liquidity, quality of productive assets and company size on the operational risk disclosure of sharia commercial bank (study on 
sharia banking in indonesia). European Journal of Business and Mangement, 10(18), 1-10. Retrieved from https://iiste.org/Journals/index.php/EJBM/article/view/42974/44459.

Beekun, R. I., \& Badawi, J. A. (2005). Balancing ethical responsibility among multiple organizational stakeholders: The Islamic perspective. Journal of Business Ethics, 60(2), 131145. https://doi.org/10.1007/s10551-004-8204-5.

Bukhari, S. A. A., Hashim, F., \& Amran, A. Bin. (2020). Determinants and outcome of Islamic corporate social responsibility (ICSR) adoption in Islamic banking industry of Pakistan. Journal of Islamic Marketing. https://doi.org/10.1108/JIMA-11-2019-0226.

Cebeci, I. (2012). Integrating the social maslaha into Islamic finance. Accounting Research Journal, 25(3), 166-184. https://doi.org/10.1108/10309611211290158.

Chotib, A., \& Utami, W. (2016). Studi Kinerja PT BNI Syariah Sesudah Pemisahan (Spin Off) dari PT Bank BNI (Persero) Tbk. Akuntabilitas, 7(2), 94-108. https://doi.org/10.15408/akt.v7i2.2661.

DeFond, M. L., Raghunandan, K., \& Subramanyam, K. R. (2002). Do non-audit service fees impair auditor independence? Evidence from going concern audit opinions. Journal of Accounting Research, 40(4), 1247-1274. https://doi.org/10.1111/1475-679X.00088.

Demirgüç-Kunt, A., \& Huizinga, H. (2010). Bank activity and funding strategies: The impact on risk and returns. Journal of Financial Economics, 98(3), 626-650. https://doi.org/10.1016/j.jfineco.2010.06.004.

Dusuki, A. W. (2008). Understanding the objectives of Islamic banking: a survey of stakeholders' perspectives. International Journal of Islamic and Middle Eastern Finance and Management, 1(2), 132-148. https://doi.org/10.1108/17538390810880982.

Erlangga, O. P., \& Mawardi, I. (2017). Pengaruh Total Aktiva, Capital Adequacy Ratio (CAR), Finance To Deposit Ratio (FDR) Dan Non Performing Financing (NPF) Terhadap Return On Assets (ROA) Bank Umum Syariah Di Indonesia Periode 20102014. Jurnal Ekonomi Syariah Teori Dan Terapan, 3(7), 561. https://doi.org/10.20473/vol3iss20167pp561-574.

Fathonih, A., Anggadwita, G., \& Ibraimi, S. (2019). Sharia venture capital as financing alternative of Muslim entrepreneurs: Opportunities, challenges and future research directions. Journal of Enterprising Communities, 13(3), 333-352. https://doi.org/10.1108/JEC-11-2018-0090.

Hassan, A., \& Syafri Harahap, S. (2010). Exploring corporate social responsibility disclosure: the case of Islamic banks. International Journal of Islamic and Middle Eastern Finance and Management, 3(3), 203-227. https://doi.org/10.1108/17538391011072417.

Hidayah, N., Badawi, A., \& Nugroho, L. (2019). Factors Affecting The Disclosure of Sustainability Reporting. International International of Commerce of Commerce and and Finance, 5(2), 219-229. Retrieved from http://oaji.net/articles/2019/27481570516215.pdf. 
KNKS, K. N. K. S. (2019). Global Islamic Finance Report 2019 places Indonesia in the Top Position in the Global Islamic Financial Market. Jakarta. Retrieved from www.knks.go.id.

Nastiti, N. D., \& Kasri, R. A. (2019). The role of banking regulation in the development of Islamic banking financing in Indonesia. International Joumal of Islamic and Middle Eastern Finance and Management, 12(5), 643-662. https://doi.org/10.1108/IMEFM-10-20180365.

Nugroho, L., Mastur, A. A., Harnovinsah, \& Aryanti, W. (2020). The Contribution of Islamic Bank in Poverty Alleviation. Al-Ahkam Jurnal Pemikiran Hukum Islam, 30(1), 19-38. https://doi.org/10.21580/ahkam.2020.30.1.5387.

Nugroho, L., \& Nugraha, E. (2020). The Role of Islamic Banking and E-Commerce for The Development of Micro, Small, and Medium Entrepreneur Businesses. Business, Economics and Management Research Journal - BEMAREJ, 3(1), 11-24. Retrieved from https://dergipark.org.tr/en/download/article-file/1084680.

Nugroho, L., Utami, W., Sukmadilaga, C., \& Fitrijanti, T. (2017). The Urgency of Allignment Islamic Bank to Increasing the Outreach. International Journal of Economics and Financial Issues, 7(4), 283-291. Retrieved from https://www.econjournals.com/index.php/ijefi/article/view/4493/pdf.

Nugroho, L., Villaroel, W., \& Utami, W. (2018). The Challenges of Bad Debt Monitoring Practices in Islamic Micro Banking. European Journal of Islamic Finance, 11, 1-11. Retrieved from http://www.ojs.unito.it/index.php/EJIF.

Prasetiyo, L. (2012). Perkembangan Bank Syariah Pasca UU 21 Tahun 2008. Al-Tahrir: Jurnal Pemikiran Islam, 12(1), 43. https://doi.org/10.21154/al-tahrir.v12i1.46.

Rammal, H. G., \& Zurbruegg, R. (2007). Awareness of Islamic banking products among Muslims: The case of Australia. Journal of Financial Services Marketing, 12(1), 65-74. https://doi.org/10.1057/palgrave.fsm.4760060.

Riyadi, S., \& Yulianto, A. (2014). Pengaruh Pembiayaan Bagi Hasil, Pembiayaan Jual Beli, Financing To Deposit Ratio (Fdr) Dan Non Performing Financing (Npf) Terhadap Profitabilitas Bank Umum Syariah Di Indonesia. Accounting Analysis Journal, 3(4), 466474. https://doi.org/10.15294/aaj.v3i4.4208.

Wibowo, E. S., \& Syaichu, M. (2013). Analisis pengaruh suku bunga, inflasi, car, bopo, npf terhadap profitabilitas bank syariah. Diponegoro Journal of Managemen, 2(2), 10-19. Retrieved from https://ejournal3.undip.ac.id/index.php/djom/article/view/2651.

Widigdo, A. M. N., Imin, M., \& Fahmi, I. (2016). Business Process Improvement of Funding: A Proposition to Increase the Performance of Indonesian Islamic Banking. Journal of Islamic Finance, 5(2), 66-79. https://doi.org/10.12816/0045118.

Widyaningrum, L., \& Septiarini, D. F. (2015). Pengaruh Car, Npf, Fdr, Dan Oer Terhadap Roa Pada Bank Pembiayaan Rakyat Syariah di Indonesia. Jurnal Ekonomi Syariah Teori Dan Terapan, 2(12), https://doi.org/970-985. 10.20473/vol2iss201512pp970-985.

Yunus, D., \& Muslimin, J. (2020). Debt in the Perspective of Islamic Law. Jurnal Syarikah: Jurnal Ekonomi Islam, 6(1), 22. https://doi.org/10.30997/jsei.v6i1.2187. 